\title{
Culture of Harpacticoid Copepods: Understanding the Reproduction and Effect of Environmental Factors
}

\author{
Kassim Zaleha and Ibrahim Busra \\ Universiti Malaysia Terengganu \\ Malaysia
}

\section{Introduction}

The availability of highly nutritive and inexpensive live food is a subject of major concern in aquaculture industry particularly for the fry production activity. For so long, the aquaculture industry has relied primarily on brine shrimp and rotifers to provide the necessary nutrition for rearing the early life stages of fish and crustaceans. Brine shrimp and rotifers are almost not suitable as first feed for fish larvae due to inappropriate size (too large or too little) (van der Meeren, 1991; Pepin \& Penney, 1997), their swimming behavior makes them less susceptible to predation (Buskey et al., 1993; von Herbing \& Gallagher, 2000), and insufficiently nutritious (Støttrup \& Norsker, 1997). Because of these problems, brine shrimp and rotifers become uneconomical as live food. This initiate the great interest in the identification of alternative live feeds to meet the demands of the aquaculture industry.

Copepods are among the most abundant and important components of aquatic invertebrates in many marine and freshwater ecosystem. They become the major biomass in zooplankton community in the water column, and at many occassions they form significant entity of benthic community structure on bottom sediment.They are a major food source for organisms in higher tropic level such as juvenile fishes and shrimps (Vincx, 1996; Penchenik, 2005) thus they become link between primary producer and other consumers in the natural food-web.

There have been a number of studies providing evidences of the effectiveness of copepods as a food item, and many investigators reported a good growth and survival of fish larvae and crustaceans fed with copepods as test food organisms (van de Meeren, 1991; Holmefjord et al., 1993; Naess et al., 1995; Støttrup \& Nosker, 1997). This is due to the good nutritional profile of copepods which meets the nutritional requirements of marine fish and crustaceans larvae as they are rich in essential fatty acids (Støttrup \& Norsker, 1997).

Amongs the copepod group, harpacticiod copepods are known to be mostly benthic (Pechenik, 2005), meaning they live on bottom habitat such as sediment or bottom vegetation. They could live as epi-(dwelling on the bottom surface), endo-(burrowing into bottom surface) or mesobenthos (living between grain particles or in pore water in the bottom sediment). As they lead a benthic living mode, they depend on the diets available on bottom habitat including phytobenthos, microbes and detritus. 
Harpacticoid copepods has been found to be a good candidate in aquaculture industry since they have a high reproductive potential, short generation time, high population growth, flexible in diet and tolerate a wide range of environmental factors such as temperature and salinity (Sun \& Fleeger, 1995; Støttrup \& Norsker, 1997). They provide a broad spectrum of prey sizes suitable for fish larvae (Gee, 1989). There are reports that indicate the availability of enzyme in harpacticoid copepods which enable the organisms to convert any type of their organic food into lipids stored in their body (Nanton \& Castel 1998; Drillet et al. 2011).

The prominent problem in using copepods as live feed in aquaculture industry is to get high yield due to several reasons which mainly related to the culture technique. Pure culture is difficult to maintain in ponds or in hatchery on a continuous basis. Although continuous cultivation of marine copepods has been achieved, but it is only for a small number of species. Several species of harpacticoid copepods that have been cultivated either for commercial use or laboratory level are Tisbe holoturidae, Tisbe beminiensis, Nitokra lacustris and Tigriopus japonicus. As reviewed by Rippingale and Payne (2001), harpacticoid copepods especially Tisbe spp (Støttrup \& Norsker, 1997) and Tigriopus spp (Carli et al., 1995) were the easiest to culture. Nevertheless, the technology to economically culture marine copepods to get highly enough yield is still being developed to date (Marcus \& Murray, 2001; Rhodes, 2003; Drillet et al., 2006).

Lacking in information about the basic biology, reproduction and response of copepods in rearing environment could be one of the reason why mass culture technique is yet to be successful for copepod production. Harpacticoid copepods in particular need special attention as they are predominantly benthic in nature. This chapter will discuss on important aspects in rearing harpacticoid copepods as live feeds in aquaculture.

\section{Reproductive biology and effect of environmental factors}

The first step to understand how to culture harpacticoid copepod is to know the reproductive biology of this animal when kept under culture condition where temperature and salinity would easily change. Copepods such as Calanoides acutus, Rhincalanus gigas, Calanus propinguus, Paraeuchaeta Antarctica showed a higher metabolic rate in the summer than in the winter (Kawall et al., 2001). It seemed that increasing in temperature will increase the respiration rate and it has positive correlation with the relative biomass of copepods (Le Borgne, 1982). For harpacticoid copepods, a number of researchers have documented that temperature is the major factor controlling the reproductive activity in the harpacticoid copepods. For example, the optimum temperature for the maximum production of the Tisbe battagliai in the laboratory condition was $20^{\circ} \mathrm{C}$ (Williams \& Jones, 1999).

The optimal conditions for the temperate is differ from the tropical species due to its natural environment. Local adaptation in term of reproductive traits could happen in order for the copepod to maximise available energy with changing temperature. This was shown by the population of harpacticoid Scottolana canadensis from different lattitude (Lonsdale \& Levinton, 1986; 1989). William \& Jones (1999) noted that under optimal conditions in the laboratory (high quantity of algal food and temperature $20^{\circ} \mathrm{C}$ ), Tisbe battagliai developed rapidly from hatching to the adult stage, have a rapid generation time and produce in quick succession, numerous broods containing large numbers of offspring. Females that were reared at $15^{\circ} \mathrm{C}$ lived twice as long as compared to $25^{\circ} \mathrm{C}$. Increasing in temperature $\left(>25^{\circ} \mathrm{C}\right)$ will decrease the number of offspring per day. 
Salinity affects the functional and structural responses of invertebrates through many aspect such as changes in total osmo-concentration, relative proportion of solutes, coefficient of absorption and saturation of dissolved gases (Kinne, 1964). Changes in total osmoconcentration could considerably modify rates of metabolism and activity. This is because of the influence of salinity variations on several biochemical and physiological mechanisms which the function is essential for survival in marine organisms (Fava \& Martini, 1988). A study on harpacticoid copepod, Tigriopus californicus showed that high salinity slowed down their growth rate and delayed the maturation time. A decrease in reproductive rate at increasing salinity caused moderate decrease in total number of clutches (Dybdahl, 1995). Gaudy et al. (1982) reported that the egg sac production and offspring survival of Tisbe holothuriae increased at higher salinities $(28-30 \mathrm{ppt})$. However, the net reproductive rate of $T$. holothuriae declined at salinities above and below 38 ppt (Miliou \& MoraitouApostolopoulou, 1991). The production of fewer offspring per egg sac and an increment in mortality had been observed.

The salinity tolerance was different at each life cycle stage, and in different sex (Damgaard \& Davenport, 1994). In most species, the narrowest tolerance rate is during very early stages, which later increased and finally decreased again in the adult stage. The narrowest range of tolerance is often associated to the period of embryonic development. Nauplii are commonly less sensitive, and during early growth could even tolerate wider salinity range and more pronounced to salinity fluctuations than adult individuals (Milione \& Zeng, 2008).

\subsection{Investigation on reproductive biology of a harpacticoid copepod, Pararobertsonia sp.}

A harpacticoid copepod, Pararobertsonia sp. was first collected during an ecological survey in an estuary in Terengganu, Malaysia $\left(5^{\circ} 02.260^{\prime} \mathrm{N}, 103^{\circ} 17.821^{\prime} \mathrm{E}\right)$. The estuary is located at the river mouth of Merchang River, meeting the South China Sea. It is inhabited by large coverage of small seagrass, Halodule pinifolia and oysters farming activities by local people. During field sampling, a $62 \mu \mathrm{m}$ net was towed horizontally on the surface of exposed seagrass patches to catch the copepods. The trapped samples were placed into container filled with seawater and aeration was provided. The collected samples were transported back to Institute of Oceanography Laboratory, Universiti Malaysia Terengganu (UMT).

In laboratory, isolation process was carried out to separate Pararobertsonia sp. from other benthic copepods. Harpacticoids carrying egg sacs were isolated from samples under a Leica ZOOM 2000 dissecting microscope using an Irwin Loop and placed individually into a petri dish $60 \times 15 \mathrm{~mm}$ containing $5 \mathrm{ml}$ of filtered-autoclaved seawater (Støttrup \& Norsker, 1997) and $1 \mathrm{ml}$ of baker's yeast (0.02 g/L) (Nanton \& Castell, 1998). The experiment was maintained closest to the normal habitat condition at temperature $26^{\circ} \mathrm{C}$ to $27^{\circ} \mathrm{C}$ and salinity 24 to 26 ppt. Each plate was initiated with single gravid copepod to ascertain monospecific culture. The culture was maintained separately until the identification was carried out for species confirmation.

After being isolated and identified, there are several steps need to be completed before culture of harpacticoid can be successfully maintained in laboratory for any investigation. These include activities such as breeding and up-scaling under laboratory condition. Water as culture media need to be treated and conditioned to meet the copepod's environment requirement. 
Data recorded were analysed using statistical analysis of variance (ANOVA) at 0.05 level of probability. Kolmogorov-Smirnov tests were used to test for the normality respectively before the comparisons. The differences on the effects of temperature and salinity were compared using Univariate ANOVA. One-way ANOVA was used to test the differences on the effects of $\mathrm{pH}$. Tukey's multiple comparison procedure was used to compare the significant differences between treatment means. All statistical analyses were performed using SPSS program, version 11.5.

\subsubsection{Establishing a stock culture}

Seawater was filtered through GFC membrane filter after passed through UV treatment before use. A $500 \mathrm{ml}$ and $1000 \mathrm{ml}$ beakers were used as culture vessel. The culture was maintained at temperature between $26^{\circ} \mathrm{C}$ to $27^{\circ} \mathrm{C}$ and salinity between 22 to $26 \mathrm{ppt}$. Culture was fed daily with $1 \mathrm{ml}$ of baker's yeast $(0.02 \mathrm{~g} / \mathrm{L})$ (Nanton and Castell, 1998) and with mixed algal (Isochrysis sp., Nannochloropsis sp., Chaetoceros sp.) at the density of $1 \times 10^{6}$ cell $/ \mathrm{ml}$. No aeration was provided for the $500 \mathrm{ml}$ and $1000 \mathrm{ml}$ stock cultures. The partial replacement of seawater was done every three days and full replacements at every month by passing the cultures through a $45 \mu \mathrm{m}$ mesh net. The trapped copepods were then transferred into new culture vessel.

\subsubsection{Determination of eggs' number}

Total of 150 to 200 individual copepodids regardless of sex were isolated from the stock culture and observation was made several times everyday for any gravid female. After few days, 30 gravid females were collected and transferred into a vial and fixed with a few drops of $5 \%$ buffered formalin. The number of eggs was counted under Leica DME compound microscope for each individual.

\subsubsection{Determination of lifespan, egg production and development}

Prior to the experiments, 30 mating pairs were isolated and placed individually in a small petri dish $(60 \times 15 \mathrm{~mm})$ containing $5 \mathrm{ml}$ new culture medium. The cultures were maintained at temperature $26-27^{\circ} \mathrm{C}$ and salinity of $22-26$ ppt. Chaetoceros sp. was offered at the density 1 $x 10^{6} \mathrm{cell} / \mathrm{ml}$. Each dish was examined daily for the first appearance of the egg sac before removing the males. This was done to ensure the number of sacs per female from its first copulation.

Each dish was examined daily at six hours intervals each day to ascertain the time of egg release and the appearance of the next egg sac. Once a female released all eggs, it will be transferred to a new dish with fresh culture medium for further observation. This was repeated until all of the females died. The daily routine consisted of checking each individual for egg development and duration under a Leica ZOOM 2000 dissecting microscope. Food was added every other day in the same concentration of $1 \times 10^{6} \mathrm{cell} / \mathrm{ml}$. The total number of egg sacs per female, maturation time of egg sacs (time between the appearance of the egg sac and its hatching), interval time between egg sacs (time between hatching and the appearance of the next egg sac for one fertilization) and lifespan of female were determined. 


\subsection{Effect of temperature and salinity on reproductive biology of a harpacticoid copepod, Pararobertsonia sp.}

Gravid females of Pararobertsonia sp. from the first copulation were selected for this study as to ensure that the next generation (nauplii) were exposed to the specified temperature and salinity regime designed in the experiment. Table 1 summarizes the combination of treatments designed for the harpacticoids.

\begin{tabular}{|c|c|c|c|}
\hline Temperature $(\mathrm{oC})$ & Salinity $(\mathrm{ppt})$ & Treatment Label & Number of replicate \\
\hline 5 & 5 & $\mathrm{~T}_{\mathrm{L}} \mathrm{S}_{\mathrm{L}}$ & 5 \\
\hline & 25 & $\mathrm{~T}_{\mathrm{L}} \mathrm{S}_{\mathrm{C}}$ & 5 \\
\hline & 45 & $\mathrm{~T}_{\mathrm{L}} \mathrm{S}_{\mathrm{H}}$ & 5 \\
\hline 25 & 5 & $\mathrm{~T}_{\mathrm{C}} \mathrm{S}_{\mathrm{L}}$ & 5 \\
\hline & 25 & $\mathrm{~T}_{\mathrm{C}} \mathrm{S}_{\mathrm{C}}$ & 5 \\
\hline & 45 & $\mathrm{~T}_{\mathrm{C}} \mathrm{S}_{\mathrm{H}}$ & 5 \\
\hline 45 & 5 & $\mathrm{~T}_{\mathrm{H}} \mathrm{S}_{\mathrm{L}}$ & 5 \\
\hline & 25 & $\mathrm{~T}_{\mathrm{C}} \mathrm{S}_{\mathrm{C}}$ & 5 \\
\hline & 45 & $\mathrm{~T}_{\mathrm{H}} \mathrm{S}_{\mathrm{H}}$ & 5 \\
\hline
\end{tabular}

Table 1. Combination of different temperature and salinity treatment for the harpacticoid copepod culture (Key: T=Temperature; $\mathrm{S}=$ Salinity; ${ }_{\mathrm{L}}=$ Low ${ }_{\mathrm{H}}=$ High; $\mathrm{C}_{\mathrm{C}}=$ Control)

Nine different treatments were prepared $\left(\mathrm{T}_{\mathrm{L}} \mathrm{S}_{\mathrm{L}}, \mathrm{T}_{\mathrm{L}} \mathrm{S}_{\mathrm{C}}, \mathrm{T}_{\mathrm{L}} \mathrm{S}_{\mathrm{H}}, \mathrm{T}_{\mathrm{C}} \mathrm{S}_{\mathrm{L}}, \mathrm{T}_{\mathrm{C}} \mathrm{S}_{\mathrm{C}}, \mathrm{T}_{\mathrm{C}} \mathrm{S}_{\mathrm{H}}, \mathrm{T}_{\mathrm{H}} \mathrm{S}_{\mathrm{L}}, \mathrm{T}_{\mathrm{H}} \mathrm{S}_{\mathrm{C}}\right.$ and $\mathrm{T}_{\mathrm{H}} \mathrm{S}_{\mathrm{H}}$ ) to determine the effects of different temperature and salinity on the reproduction and development of Pararobertsonia sp. The experiment was conducted in three different temperatures; $5^{\circ} \mathrm{C}, 25^{\circ} \mathrm{C}$ and $45^{\circ} \mathrm{C}$. In each temperature setup, copepods were treated with three salinity levels; $5 \mathrm{ppt}, 25 \mathrm{ppt}$, and $45 \mathrm{ppt}$. All copepods were gradually exposed to the lower $\left(5^{\circ} \mathrm{C}\right)$ and higher $\left(45^{\circ} \mathrm{C}\right)$ temperature from the control value $\left(25^{\circ} \mathrm{C}\right)$ before the experiment started to avoid shock effect which would instantly kill the animal. The same treatment was also applied for salinity exposure.

\subsection{Results}

\subsubsection{Lifespan, egg production and development in Pararobertsonia sp.}

Lifespan of 30 individual females of Pararobertsonia sp. was determined in this experiment by measuring the length of time from first day of hatching as nauplii until they died under laboratory control condition at temperature $25^{\circ} \mathrm{C}$ and salinity $25 \mathrm{ppt}$. The average lifespan of a female Pararobertsonia sp. was $31.2 \pm 3.57$ days with a minimum and maximum of 26.0 and 40.0 days respectively.

The interval time between the production of egg sac is measured as time between hatching and the appearance of the next egg sac from one fertilization event. The maturation time of egg sac was determined as the time between the appearance of eggs and its hatching time. A female of Pararobertsonia sp. appears to produce several egg sacs from one fertilization event. The total number of egg sac per female had large fluctuation and significantly different among the 30 individual copepods observed. Total number of egg sacs per female was $6.7 \pm$ 2.54 egg sacs in average, where the minimum and maximum was 3.0 and 12.0 egg sacs 
respectively. Mean total number of eggs per sac was $21.7 \pm 4.79$ eggs. The total number of eggs per sac ranged between 14.0 and 30.0 eggs per sac.

The time of formation between first egg sacs and the next was recorded within 0 to 11 hours. The egg sac could be seen in the oviduct within minimum hours range from 0 to 11 hours and maximum hours range from 60 to 71 hours after the previous egg release. The time between hatching and the appearance of the next egg sacs was significantly frequent within 0 to 11 hours with $65.88 \%$ and less frequent within 60 to 71 hours with $1.18 \%$ (Figure 1).

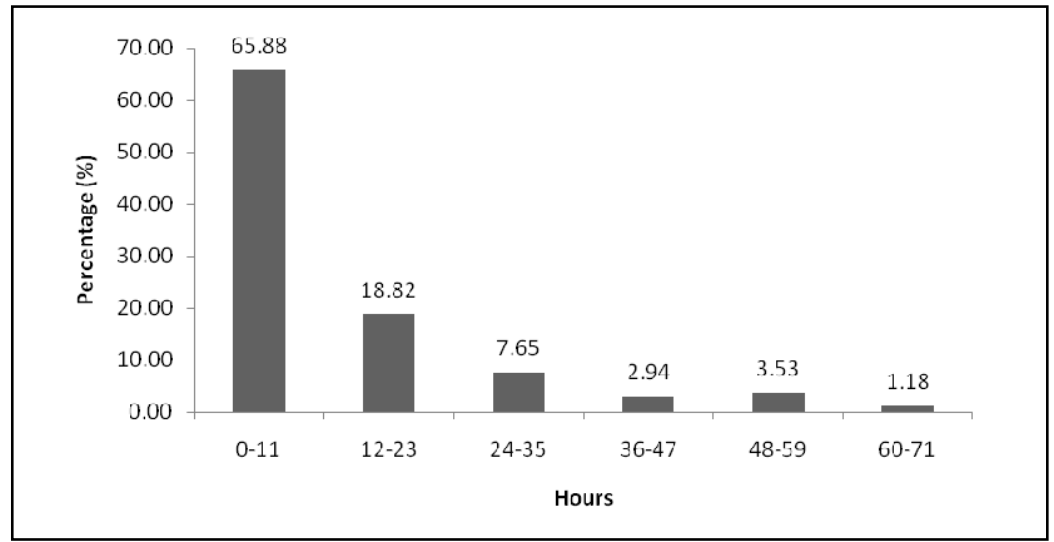

Fig. 1. The percentage (\%) of interval time between egg sacs of a female Pararobertsonia sp. under laboratory control condition (temperature $25^{\circ} \mathrm{C}$; salinity $25 \mathrm{ppt}$ ).

A female could have different maturation time for each interval of their production of egg sac. Figure 2 shows the percentage (\%) of maturation time for each individual female to carry their eggs until its hatching. Time (hours) recorded for eggs to be released and hatched

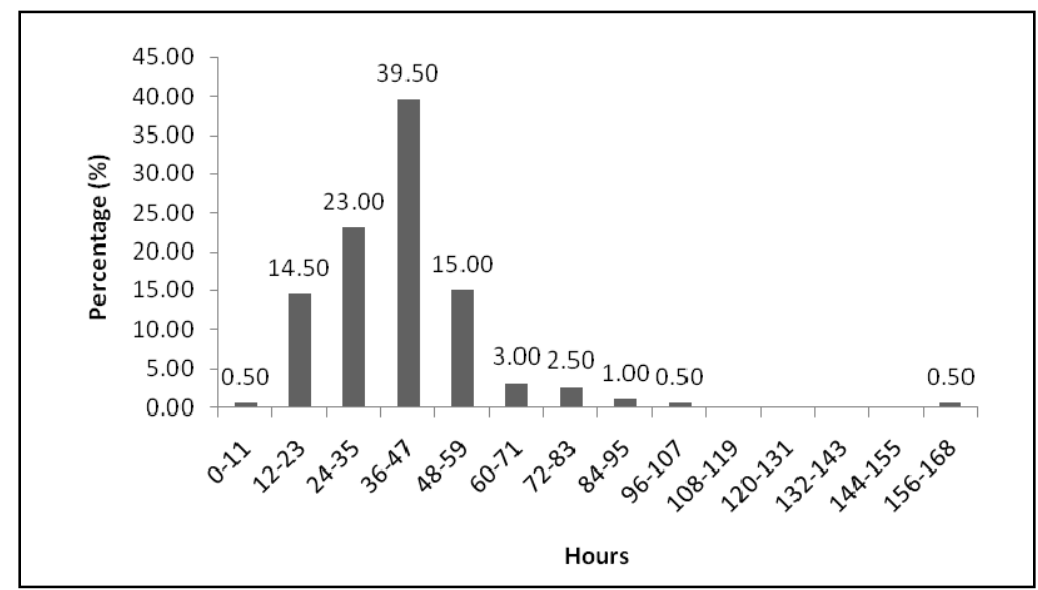

Fig. 2. The percentage (\%) of eggs and their maturation time for a female Pararobertsonia sp. under laboratory controlled condition (temperature $25^{\circ} \mathrm{C}$; salinity $25 \mathrm{ppt}$ ). 
was within 0 to 11 hours until 156 to 167 hours. However, most of the eggs (39.50\%) were matured and hatched within 36 to 47 hours while only $1 \%$ took 0 to 11 hours, 96 to 107 hours and 156 to 168 hours to hatch. It shows that the maturation time of eggs was shorter at early and longer for the late egg sacs produced.

\subsubsection{Effect of temperature and salinity}

In general, there is no significant effect of different salinity on the production of eggs/sac of copepod for each temperature treatment (Table 2). Despite the large difference in salinity (5$45 \mathrm{ppt})$, the number of eggs produced in each egg sac of a female was more or less the same when cultured under the same temperature. Decrement of temperature reduced the number of eggs/sac more than when they were exposed to the increment of temperature to $45^{\circ} \mathrm{C}$. Copepods cultured in $25^{\circ} \mathrm{C}$ produced significantly high number of eggs if compared to $5^{\circ} \mathrm{C}$ and $45^{\circ} \mathrm{C}$.

\begin{tabular}{|c|c|c|c|}
\hline Temperature $\left({ }^{\circ} \mathrm{C}\right)$ & Salinity $(\mathrm{ppt})$ & Treatment Label & Number of eggs/sac \\
\hline 5 & 5 & $\mathrm{~T}_{\mathrm{L}} \mathrm{S}_{\mathrm{L}}$ & $11.6 \pm 1.14$ \\
\hline & 25 & $\mathrm{~T}_{\mathrm{L}} \mathrm{S}_{\mathrm{C}}$ & $10.8 \pm 2.59$ \\
\hline & 45 & $\mathrm{~T}_{\mathrm{L}} \mathrm{S}_{\mathrm{H}}$ & $11.6 \pm 1.82$ \\
\hline 25 & 5 & $\mathrm{~T}_{\mathrm{C}} \mathrm{S}_{\mathrm{L}}$ & $24.4 \pm 4.72$ \\
\hline & 25 & $\mathrm{~T}_{\mathrm{C}} \mathrm{S}_{\mathrm{C}}$ & $23.8 \pm 2.87$ \\
\hline & 45 & $\mathrm{~T}_{\mathrm{C}} \mathrm{S}_{\mathrm{H}}$ & $23.8 \pm 8.14$ \\
\hline 45 & 5 & $\mathrm{~T}_{\mathrm{H}} \mathrm{S}_{\mathrm{L}}$ & $22.8 \pm 5.76$ \\
\hline & 25 & $\mathrm{~T}_{\mathrm{C}} \mathrm{S}_{\mathrm{C}}$ & $19.8 \pm 7.85$ \\
\hline & 45 & $\mathrm{~T}_{\mathrm{H}} \mathrm{S}_{\mathrm{H}}$ & $15.0 \pm 1.41$ \\
\hline
\end{tabular}

Table 2. The number of eggs/sac/female copepod Pararobertsonia sp. reared under different temperature and salinity

The number of offspring and their survival is shown in Figure 3. No nauplii survived to the next life-stage at $5^{\circ} \mathrm{C}$. On the other hand, survival significantly increase $(\mathrm{p}<0.05)$ at $25^{\circ} \mathrm{C}$. Copepods in $45^{\circ} \mathrm{C}$ treatment showed the same pattern of development as in low temperature $\left(5^{\circ} \mathrm{C}\right)$. Increase of temperature up to $45^{\circ} \mathrm{C}$ still permit gravid females to produce high number of eggs/sac despite being exposed to different salinity although no survival to adult stages were observed.

Table 3 summarizes the data on maturation and generation time from the present study. Different temperatures were significantly affected (ANOVA, $\mathrm{P}<0.05$ ) the maturation time of egg sacs while no significant difference (ANOVA, P>0.05) was observed among the salinities in every temperature treatments. The mean maturation time of egg sacs was shortest at high temperature $\left(45^{\circ} \mathrm{C}\right)$ and longest at control temperature $\left(25^{\circ} \mathrm{C}\right)$.

No data on generation time was recorded for $5^{\circ} \mathrm{C}$ due to the delay in the development of nauplii into the copepodite stage throughout the study period (20 days). At $45^{\circ} \mathrm{C}$, the only data obtained was on generation time from nauplii to copepodite as no copepods survived to the adult stage. The mean generation time from copepodite to adult at $25^{\circ} \mathrm{C}$ was longest in low salinity ( $3.2 \pm 0.84$ days) and shortest in high salinity ( $2.0 \pm 0.71$ days). However, the mean generation time from nauplii to gravid female was longest in high salinity with $8.8 \pm$ 

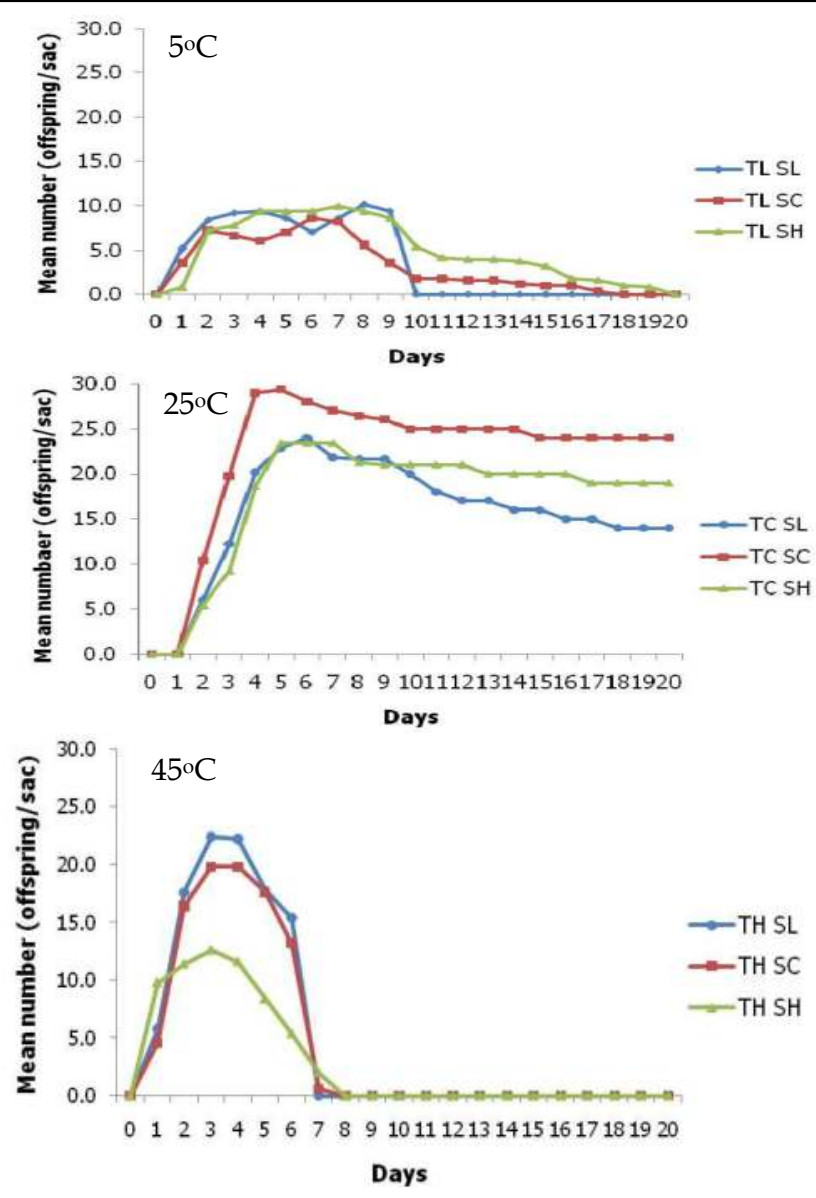

Fig. 3. Mean number of offspring per egg sac per female harpacticoid Pararobertsonia sp. at low $\left(5^{\circ} \mathrm{C}\right)$, control $\left(25^{\circ} \mathrm{C}\right)$ and high $\left(45^{\circ} \mathrm{C}\right)$ temperature and low $(5 \mathrm{ppt})$, control $(25 \mathrm{ppt})$ and high (45ppt) salinity. Key: T=Temperature; $\mathrm{S}=$ Salinity; ${ }_{\mathrm{L}}=$ Low; ${ }_{\mathrm{H}}=$ High; $\mathrm{C}=$ Control

1.10 days. The shortest generation time was in control condition $25^{\circ} \mathrm{C}$ and $25 \mathrm{ppt}(7.3 \pm 0.96$ days). The longest generation time from N1 to C1 was obtained from copepod reared in high salinity with $3.8 \pm 0.45$ days while the shortest of the generation time was observed in low salinity with $2.2 \pm 0.45$ days.

\subsection{Discussion}

\subsubsection{Reproductive biology and development of Pararobertsonia sp.}

Detail report on reproduction and development in copepods particularly harpacticoids were mostly from the temperate species (Hicks \& Coull, 1983; Sun \& Fleeger, 1995; William \& Jones, 1999; Rhodes, 2003). Pararobertsonia sp. is a tropical harpacticoid that has been 
Culture of Harpacticoid Copepods:

\begin{tabular}{|c|c|c|c|c|c|}
\hline $\begin{array}{c}\text { Temperature } \\
\left({ }^{\circ} \mathrm{C}\right)\end{array}$ & Treatment & $\begin{array}{c}\text { Maturation } \\
\text { time of egg } \\
\text { sacs (days) }\end{array}$ & $\begin{array}{c}\text { Generation } \\
\text { time from N1- } \\
\text { C1 (days) }\end{array}$ & $\begin{array}{c}\text { Generation } \\
\text { time from C1- } \\
\text { Adult (days) }\end{array}$ & $\begin{array}{c}\text { Generation } \\
\text { time from N1- } \\
\text { Gravid (days) }\end{array}$ \\
\hline 5 & $\mathrm{~T}_{\mathrm{L}} \mathrm{S}_{\mathrm{L}}$ & $1.6^{\mathrm{a}} \pm 0.55$ & $0.0 \pm 0.00$ & $0.0 \pm 0.00$ & $0.0 \pm 0.00$ \\
& $\mathrm{~T}_{\mathrm{L}} \mathrm{S}_{\mathrm{C}}$ & $2.0^{\mathrm{a}} \pm 1.22$ & $0.0 \pm 0.00$ & $0.0 \pm 0.00$ & $0.0 \pm 0.00$ \\
& $\mathrm{~T}_{\mathrm{L}} \mathrm{S}_{\mathrm{H}}$ & $2.0^{\mathrm{a}} \pm 0.71$ & $0.0 \pm 0.00$ & $0.0 \pm 0.00$ & $0.0 \pm 0.00$ \\
\hline 25 & $\mathrm{~T}_{\mathrm{C}} \mathrm{S}_{\mathrm{L}}$ & $2.6^{\mathrm{a}} \pm 0.89$ & $2.4^{\mathrm{a}} \pm 0.55$ & $3.2^{\mathrm{a}} \pm 0.84$ & $8.6^{\mathrm{a}} \pm 1.52$ \\
& $\mathrm{~T}_{\mathrm{C}} \mathrm{S}_{\mathrm{C}}$ & $2.0^{\mathrm{a} \pm 0.00}$ & $2.3^{\mathrm{a} \pm 0.50}$ & $3.0^{\mathrm{a}} \pm 0.82$ & $7.3^{\mathrm{a}} \pm 0.96$ \\
& $\mathrm{~T}_{\mathrm{C}} \mathrm{S}_{\mathrm{H}}$ & $2.2^{\mathrm{a}} \pm 0.45$ & $3.8^{\mathrm{a} \pm 0.45}$ & $2.0^{\mathrm{a}} \pm 0.71$ & $8.8^{\mathrm{a}} \pm 1.10$ \\
\hline 45 & $\mathrm{~T}_{\mathrm{H}} \mathrm{S}_{\mathrm{L}}$ & $1.2^{\mathrm{b} \pm 0.45}$ & $2.2^{\mathrm{a} \pm 0.45}$ & $0.0 \pm 0.00$ & $0.0 \pm 0.00$ \\
& $\mathrm{~T}_{\mathrm{H}} \mathrm{S}_{\mathrm{C}}$ & $1.0^{\mathrm{b} \pm 0.00}$ & $2.4^{\mathrm{a} \pm 0.55}$ & $0.0 \pm 0.00$ & $0.0 \pm 0.00$ \\
& & & & & \\
& $\mathrm{~T}_{\mathrm{H}} \mathrm{S}_{\mathrm{H}}$ & $1.0^{\mathrm{b}} \pm 0.00$ & $3.3^{\mathrm{a} \pm 0.58}$ & $0.0 \pm 0.00$ & $0.0 \pm 0.00$ \\
\hline
\end{tabular}

Table 3. Maturation time of egg sacs (time between the appearance of egg and hatching), generation time from Nauplii I to Copepodite I, generation time from Copepodite I to Adult and generation time from Nauplii I to gravid female of Pararobertsonia sp. at different temperatures $\left(5^{\circ} \mathrm{C}, 25^{\circ} \mathrm{C}\right.$ and $\left.45^{\circ} \mathrm{C}\right)$ and salinities ( $5 \mathrm{ppt}, 25 \mathrm{ppt}$ and $45 \mathrm{ppt}$ ). Means in the column with the same superscript are not significantly different $(\mathrm{P}>0.05)$.

successfully cultured in our laboratory environment for many generations since 2007, but the detail of the reproductive biology and development stage has never been reported before. The probability for a female Pararobertsonia sp. to produce multiple egg sacs from one fertilization event is very high, the same as for other harpacticoids. The gravid female can be gravid for several times in a short period without remating. Hicks \& Coull (1983) reported that the number of sacs produced from a single copulation vary from four to 12 for five species of Tisbe and three to 21 for other 21 species of harpacticoids. A female of Tisbe biminiensis produced up to nine egg sacs during its life (Pinto et al., 2001), while Tisbe battagliai fed on Isochrysis galbana Parke produced $5.3 \pm 2.2$ egg sacs when cultured under temperature $25^{\circ} \mathrm{C}$ and salinity 25 ppt (William \& Jones, 1999).

Many researchers have shown that egg production in copepod is different for each individual. A study by Guérin et al. (2001) showed that the number of eggs per sac produced by Tisbe holothuriae has large fluctuation, ranging from the maximum of 133 to a minimum of only three eggs in an egg sac. Sun and Fleeger (1995) found that a harpacticoid Amphiascoides atopus (Diosaccidae) typically carries two egg sacs and the average brood size was 24 eggs per ovigerous female. The mean number of eggs per sac for T. biminiensis fed on Nitzchia closterium was $69.0 \pm 24.6$, Tetraselmis gracilis was $40.6 \pm 16.1$ and mixed of $N$. closterium and T. gracilis was $46.0 \pm 17.1$ eggs (Pinto et al., 2001). Pararobertsonia sp. in the present study produced the lower mean number of eggs per sac $(21.7 \pm 4.79)$ than above studies which could be related to the type of the given diet.

Maturation time as well as interval time between egg sacs for every individual of the same species is reported to be different and varies among each other (Tester \& Turner, 1990). 
These differences may be due to inherent biological variability which is determined partly by genetic differences. In the present study the maturation time of egg sac of individual Pararobertsonia sp. showed wide variation (0 - 167 hours). Most egg hatching took placed within 36 to 47 hours, comparable to maturation time of most harpacticoid copepods which is within 48 hours (Dam \& Lopes, 2003). Most females took the shortest time (within 11 hours) for the duration between hatching and the appearance of the next egg sac. By comparison, T. biminiensis took two days to produce a new egg sac (Pinto et al., 2001).

The lifespan of Pararobertsonia sp. cultured in temperature $25^{\circ} \mathrm{C}$, salinity $25 \mathrm{ppt}$ and fed on Chaetoceros sp. was about $31.2 \pm 3.57$ days, which is within the normal range. In comparison, lifespan of T. biminiensis cultured in temperature $28-30^{\circ} \mathrm{C}$, salinity $34 \mathrm{ppt}$ and fed on $\mathrm{N}$. closterium, T. gracilis and mixed of both diet was about $29.0 \pm 7.2,32.9 \pm 4.9$ and $32.7 \pm 4.6$ days respectively (Pinto et al., 2001). William \& Jones (1999) reported on lifespan of $T$. battagliai when fed on Isochrysis galbana Parke was $23 \pm 4.9$ at temperature $25^{\circ} \mathrm{C}$ and salinity 25 ppt. A number of factors including the difference in species, quantity and quality of the food source and environmental condition including temperature and salinity could affect the reproduction and lifespan of the species.

\subsubsection{Effects of temperature on reproduction and development}

Temperature is often the most important environmental factor affecting the productivity of copepods in natural systems (Christou \& Moraitou-Apostolopoulou, 1995; Siokou-Frangou, 1996). In general, the effects of temperature on marine copepods are well studied, but information on the effects of temperature for tropical copepod species are relatively limited. Many previous works have employed the effects of temperature on temperate harpacticoids species sush as Tisbe (Hicks \& Coull, 1983; Miliou \& Moraitou-Apostolopoulaou, 1991; Williams \& Jones, 1994). Limited number of tropical species has been used as subject matter to study the effects of temperature in culture condition, which includes Pararobertsonia sp. (Zaleha \& Farahiyah-Ilyana, 2010) and Nitocra affinis (Matias-Peralta et al., 2005).

Results from the present study showed how temperature affecting the offspring production, survival, maturation time of eggs and generation time in Pararobertsonia sp.The differences in temperature significantly affects the reproductive and development rate of Pararobertsonia sp. Low temperature delayed the development whereas high temperature increased the development rate but extreme temperatures $\left(>45^{\circ} \mathrm{C}\right)$ could lead to mortality. Temperature stress may have negative effects on survival and reproduction. These findings were relatively similar to the study of Takahashi \& Ohno (1996). The later study found that Acartia tsuensis (Copepoda: Calanoida) could develop normally from egg to adult within a temperature range of 17.5 to $30^{\circ} \mathrm{C}$ while optimum growth and minimum mortality were achieved at around $25^{\circ} \mathrm{C}$. However, the development slowed at both lower and higher ends of temperature at $17.5^{\circ} \mathrm{C}$ and $30^{\circ} \mathrm{C}$. Similar trends have also been observed in other copepod species, such as Diaptomus pallidus (Geiling \& Campbell, 1978) and Acrocalanus gibber (McKinnon, 1996).

Increased and decreased temperature also affected egg production of Pararobertsonia sp. where the egg production at decrement or increment temperature was lower compared to control temperature. This is because Pararobertsonia sp. could not adapt the environmental stress that inhibits normal gonad development and consequently affected the average number of eggs produced per female. This study is consistent with previous study by 
Miliou \& Moraitou-Apostolopoulou (1991). The later study reported that a reduction in the number of egg sacs and the total number of offspring produced by the Greek strain of Tisbe holothuriae was observed when the temperature was lower or higher than the optimum $\left(19^{\circ} \mathrm{C}\right)$. In addition, Ambler (1985) and Uriarte et al. (1998) revealed that egg production is normally lower at low temperatures and generally increase with increasing temperature up to a thermal threshold, after which decline begins. Such a trend has been reported for the egg production of Acartia tonsa (Ambler, 1985), A. clausi (Uye, 1985), A. bifilosa (Uriarte et al., 1998), A. lilljeborgi (Ara, 2001). A study on Boeckella hamata (Copepoda: Calanoida), showed that clutch size decreased with increased temperature (Hall \& Burns, 2002).

Survival of Pararobertsonia sp. in this present study was solely affected by temperature rather than salinity. Some previous studies showed that temperature has a direct influence on the survival of copepod (Peterson, 2001). The negative effects of higher temperature on the survival of Pararobertsonia sp. are similar with other previous studies. Survival of copepods and cladocerans were better at low temperature than at high temperature (Moore et al., 1996). Chinnery \& Williams (2004) found that survival, egg production and hatching rate of A. bifilosa, A. clausi, A. discaudata, and A. tonsa increased when temperature rise from 5 to $20^{\circ} \mathrm{C}$. Although increasing temperature showed the positive effects, the development and survival reduces as temperature rises beyond a certain level (Chinnery \& Williams, 2004). For example, temperatures greater than $30^{\circ} \mathrm{C}$ was unfavourable to survival, percent ovigerous females, and fecundity of Pseudodiaptomus pelagicus (Copepoda: Calanoida) (Rhyne et al., 2009).

Slight increment or decrement in temperature affected the maturation time of the egg sacs of Pararobertsonia sp. There are only few laboratory studies that have explored the relationship between temperature and development rate in the life history stages of harpacticoid copepods (Palmer \& Coull, 1980). The present study revealed similar finding as previously described by Chandler et al., (2003). The later study reported that eggs of harpacticoid copepod, Amphiasucus tenuiremis were developed in two to three days at temperature $25^{\circ} \mathrm{C}$ and salinity $30 \mathrm{ppt}$. Temperature give significant effects on the maturation time of eggs sac of copepods (McLaren et al., 1969). Evidence from some laboratory studies proved that temperature has strong influence on reproductive and postembryonic development (Hicks \& Coull, 1983; William \& Jones,1999; Matias-Peralta et al., 2005). Rhyne et al. (2009) found that 26 to $30^{\circ} \mathrm{C}$ was the best range for nauplii production while 28 to $32^{\circ} \mathrm{C}$ was the best for fast maturation rate of nauplii. A study by Williams \& Jones (1994) also noted that a benthic harpacticoid, Tisbe battagliai has their best temperature at $20^{\circ} \mathrm{C}$ and increasing of temperature towards $25^{\circ} \mathrm{C}$ decreased the production rate.

Harpacticoid copepods have short generation time as reviewed by Sun \& Fleeger (1995), Chandler et al., (2003) and McKinnon et al. (2003). However, data on the duration of the larval stages of marine harpacticoid copepods and the influence of environmental factors (specifically temperature) and their potential interaction on postembryonic development are relatively limited (Williams \& Jones, 1994). The generation time of Pararobertsonia sp. found from this present study clearly shown that temperature do affect the period between stages of life cycle. Increment in temperature decreased the development time while decrement in temperature increased the development time of Pararobertsonia sp. Hicks \& Coull, (1983) found the similar finding where the development time of Tisbe sp. decreased with increasing temperature. Tisbe sp. required high temperature (up to $25^{\circ} \mathrm{C}$ ) for faster development. In 
addition, mean development time of calanoid copepod, Pseudocalanus newmani decreased exponentially with increasing temperature and reached the shortest duration at $32^{\circ} \mathrm{C}$ (Rhyne et al., 2009). Similarly, Williams \& Jones (1994) clarified that fastest development for harpacticoid copepod T. battagliai occurred in the warmer months of the year which regarding to the highest production of superior food. However, in the present study, food was given at constant concentration.

The development time of Pararobertsonia sp. at increment temperature was two times faster compared to control and decrement temperature. Low temperature can retard activity of organisms and consequently reduces the consumption of oxygen. Whereas, high temperature can increase oxygen consumption to one point where metabolic demands exceed energy reserved. A calanoid copepod, Pseudocalanus newmani, was reported to delay the development time from 20.9 to 42.3 days when temperatures decreased from 15 to $6^{\circ} \mathrm{C}$ (Lee et al., 2003). This trend was also observed in A. clausi, where development time delayed from 35.4 to 74.8 days when temperatures decreased from 10 to $5^{\circ} \mathrm{C}$ (Chinnery \& Williams, 2004).

Some previous reports on the respond of tropical copepods to temperature stress presented similar finding with this present study. Milione \& Zeng (2008) stressed the effects of temperature on both population growth and hatching rates. The later study suggested that for maximum population growth and egg hatching success of a tropical calanoid copepod, A. sinjiensis should be cultured at $30^{\circ} \mathrm{C}$ with a salinity of $30 \mathrm{psu}$. Likewise, Matias-Peralta et al. (2005) showed that the N. affinis, grow well and achieved highest maximum production $\left(124.2 \pm 2.6\right.$ offspring female $\left.{ }^{-1}\right)$ at temperature $35^{\circ} \mathrm{C}$. In comparisons, Zaleha \& FarahiyahIlyana (2010) reported that temperature of $25 \pm 1^{\circ} \mathrm{C}$ and high salinity ( $25 \mathrm{ppt}-35 \mathrm{ppt}$ ) were the optimum condition for the maximum production $(2.3-3.7$ individual $/ \mathrm{ml})$ of a tropical Pararobertsonia sp. in the laboratory condition.

In this study, the survival and reproductive parameters of individual Pararobertsonia sp. in different temperature treatments showed wide variation. These differences caused by inherent biological variability and physiological response. Thermal stress caused energy to be allocated toward survival processes rather than reproduction. This may also be explained based on the study by Williams \& Jones (1999) where they reported that nauplii production of T. battagliai ceased after 20 days at $25^{\circ} \mathrm{C}$ while lower temperature treatments continued to produce nauplii for 36 days. The adaptation of some individuals will be better than others in respond to environmental stress due to the attributes of some individuals to establish their population (Depledge, 1990; 1994). Every metabolic rate of zooplankton such as respiration and feeding rate is dependent on temperature (Heinle, 1969). In this present study, Pararobertsonia sp. grew well and achieved high reproductive activity at temperature $25^{\circ} \mathrm{C}$, the same temperature for the stock which has been maintained for two years. In contrast, the copepods were exposed to daily change towards the required temperature in the other two experiments. This might be the reason for the different adaptability and productivity found in this study as they need to tolerate and respond to the environmental stress everyday and it could be affecting their physiological response.

\subsubsection{Effects of salinity on reproduction and development}

Although temperature is recognised as an important factor controlling reproduction in harpacticoid copepods, there are other factors which regulate reproductive activity including food resource availability, environmental stability and their effects on the 
evolution of particular life-history strategies. Some researchers revealed that salinity is one of the main environmental factors controlling species distribution, the rates of growth, developments in larvae stages and reproduction of harpacticoid copepod, especially on those with restricted capacity of osmoregulation (Miliou \& Moraitou-Apostolopoulou, 1991; Miliou, 1996).

Generally, the results of this study apparently showed that Pararobertsonia sp. could tolerate in wide variation of salinities ranging from 5 to $45 \mathrm{ppt}$. Similar results were reported by Matias-Peralta et al. (2005). They clarified that Nitocra affinis, a tropical harpacticoid could tolerate in salinities from 10 to 35 ppt. In addition, study done by Sun \& Fleeger (1995), they found that a harpacticoid Amphiascoides atopus was able to survive in a wide range of salinities $(10-60 \mathrm{ppt})$. Different salinities showed to have different effects on offspring production and survival of Pararobertsonia sp. Conversely, there are no effects shown on the number of eggs per sac, maturation time and generation time. Devreker et al. (2009) reported that the combination of salinity and temperature have different effects on the physiology of an estuary calanoida copepod, Eurytemora affinis. High salinities are most stressful for E. affinis at high temperatures (Kimmel \& Bradley, 2001). Survival of E. affinis could strongly decreased when high salinities are combined with high temperatures (Gonzalez \& Bradley, 1994).

High survival (more than $80 \%$ ) of Pararobertsonia sp. was achieved under salinity 25 to 45 ppt. Extreme low salinity (5ppt) could give significant effect on their survival. Nevertheless, they can survive in the laboratory cultures when salinity dropped gradually into $0 \mathrm{ppt}$ (personal observation). Supporting this finding, Gaudy et al. (1982) stated that decreases in salinity resulted to high mortalities of Tisbe holothuriae. Staton et al. (2002) found that there is a non-linear survival response of Microathridion littorale (estuarine harpacticoid copepod) to short term immersion of 24 hours in 3,12 and 35 psu. Copepods that were transferred in the 12 psu showed the lowest survival rate.

Although Pararobertsonia sp. has been observed to survive better at higher salinity compared to lower salinity, the generation time from nauplii to gravid female was longer under high salinity. However, the generation time from copepodite to adult was shorter under high salinity. This difference could be related to the physiological difference existing between first naupliar and late copepodite stages. Similar result was reported by Hagiwara et al. (1995) for Tisbe japonicus. They found that development time of T. japonicus was fastest at higher salinities (16 -32 ppt) and growth rate tended to be slower in low salinity.

Pararobertsonia sp. were able to reproduce and survived from the first egg sac hatched as nauplii to gravid female under different salinities ranging from 5 to $45 \mathrm{ppt}$ at temperature $25^{\circ} \mathrm{C}$ compared to higher and lower temperature. It is clearly shown that Pararobertsonia sp. could tolerate to salinity changes rather than temperature. As reported by Devreker et al., (2009), the development of estuary calanoid copepod, E. affinis appeared to be more sensitive to temperature than salinity. Lee \& Petersen, (2002) revealed that temperaturesalinity interaction effect on salinity and temperature tolerance. The tolerance to temperature and salinity stress is controlled by a group of regulatory genes as documented by Kimmel \& Bradley (2001). The genotype controls the synthesis of proteins necessary for metabolic activity. Consequently, this difference in genotype modified the metabolic performance as a function of environmental conditions. 
Under control temperature $\left(25^{\circ} \mathrm{C}\right)$, Pararobertsonia sp. showed the ability to survive and even breed in a salinity ranged of 5 to $45 \mathrm{ppt}$. This might be due to its great adaptation and osmoregulatory ability. Kimmel \& Bradley (2001) demonstrated that salinity variations induce synthesis or degradation of amino acids during osmoregulation. This generates an increase in the consumption of protein reserves as well as in energy requirements for enzymatic activity. Without energy renewal, this stress decreases copepod survivorship and causes death of the nauplius in the early stages. The present study suggests that there is no salinity stress at this range of salinity because the nauplii can develop normally to adult stage. However, harpacticoids did not survive when they were transferred directly into the salinity 5 ppt (personal observation). As reviewed by Staton et al. (2002), they noted that exposure of low salinity in more than 24 hours for Microathridion littorale (estuarine harpacticoid copepod) could lead to mortality.

Pararobertsonia sp. is regarded as an estuarine harpactiocid copepod which is considered to be exposed to large fluctuations of salinity due to tidal cycle daily. Therefore, this species could already adapted to salinity fluctuation more than the temperature changes, thus become less affected by the salinity changes in the experiment. Goolish \& Burton (1989) confirmed that the variability in individual's physiological response to salinity changes was due to the salinity history of organism and species specific hereditary traits.

\section{Conclusion}

Harpacticoid copepods are potential candidate as live feed in aquaculture. They have most of the required characteristics to replace artemia and rotifers as starter food for newly hatched fish and shrimp larvae. Nevertheless, the mass production of copepods as live feed for aquaculture purposes is still at the experimental stage and success story is limited to only few copepod species. Understanding the basic biology of the species in culture condition will help in planning and handling the copepod culture for mass production. An example given in this chapter is the reproduction and development data of a tropical harpacticoid copepod, Pararobertsonia sp. This species could produce multiple egg sacs from a single copulation, with an average of $6.7 \pm 2.47$ egg sacs (ranging from 3.0 to 12.0 egg sacs) in $31.2 \pm 3.57$ days (average of lifespan). The production of eggs per sac was $21.7 \pm 4.79$, varies from 14 to 30 eggs. The maturation time of egg sac is variable with range from 0 to 167 hours ( 7 days). However, most of the eggs were matured within 36 to 47 hours (2 days). The interval time between egg sacs varies from 0 to 71 hours ( 3 days), but most of individual took 11 hours to produce the next eggs. In this present study it is clearly shown that reproductive biology of every individual of Pararobertsonia sp. are varies among each other. Temperature appears to give significant effect on reproduction and development of Pararobertsonia sp. compared to salinity. High temperature increased while low temperature delayed the development of Pararobertsonia sp. but extreme temperature could lead to the mortality. This is particularly true if the copepod is drastically exposed to the temperature of beyond the tolerant limit. On the other hand, this species has a wide range of salinity tolerance ( 5 to $45 \mathrm{ppt}$ ). However, direct exposure to that lowest or highest salinity could lead to the mortality as well.

\section{Acknowledgment}

The study was carried out as part of a research project 'Development of cyst in marine harpacticoid copepods' funded by National Oceanographic Directorate, Ministry of Science, Technology and Innovation, Malaysia. 


\section{References}

Ambler, J.W. (1985). Seasonal factors affecting egg production and viability of eggs of Acartia tonsa Dana from East Lagoon, Galveston, Texas. Estuarine, Coastal and Shelf Science 20:743-760.

Ara, K. (2001). Daily egg production rate of the planktonic calanoid copepod Acartia lilljeborgi Giesbrecht in the Cananéia Lagoon estuarine system, Sao Paulo, Brazil. Hydrobiologia 445: 205-215.

Buskey, E.J.; Coulter, C. \& Strom, S. (1993). Locomotory patterns of microzooplankton: potential effects on food selectivity of larval fish. Bulletin of Marine Science 53:29-43.

Carli, A.; Mariottini, G.L.\& Pane, L. (1995). Influence of nutrition on fecundity and survival in Tigriopus fulvus Fischer (Copepoda, Harpacticoida). Aquaculture 134:113-119.

Chandler, G.T.; Cary, T.M.; Volz, D.C.; Walse, S.S.; Ferry, J.L. \& Klosterhaus, S.L. (2003). Fipronil effects on estuarine copepod (Amphiascus tenuiremis) development, ferility, and reproduction: A rapid life-cycle assay in 96-well microplate format. Environmental Toxicology and Chemistry 23:117-124.

Chinnery, F.E. \& Williams, J.A. (2004). The influence of temperature and salinity on Acartia (Copepoda: Calanoida) nauplii survival. Marine Biology 145:733-738.

Christou, E.D. \& Moraitou-Apostolopoulou, M. (1995). Metabolism and feeding of mesozooplankton of the eastern Mediterranean coast (Hellenic waters). Marine Ecology: Progress Series 126:39-48.

Dam, H.G. \& Lopes, R.M. (2003). Omnivory in the calanoid copepod Temora longicornis: feeding, egg production and egg hatching rates. Journal of Experimental Marine Biology and Ecology 292:119- 137.

Damgaard, R.M. \& Davenport, J. (1994). Salinity tolerance, salinity preference and temperature tolerance in the high shore copepod Tiqriopus brevicornis. Marine Biology 118:443-449.

Depledge, M.H. (1990). Interactions between heavy metals and physiological processes in estuarine invertebrates. In: P.L. Chambers and C.M. Chambers, Editors, Estuarine Ecotoxicology, JAPAGA, Ashford, Co., Wicklow, Ireland. Pp 89-100.

Depledge, M.H. (1994). Genotypic toxicity: implications for individuals and populations. Environmental Health Perspectives 102 (Supplement 12):101-104.

Devreker, D.; Souissi, S.; Winkler, G.; Forget-Leray, J. \& Leboulenger, F. (2009). Effects of salinity, temperature and individual variability on the reproduction of Eurytemora affinis (Copepoda; Calanoida) from the Seine estuary: A laboratory study. Journal of Experimental Marine Biology and Ecology 368:113-123.

Drillet, G.; Iversen, M.H.; Sørensen, T.F.; Ramløv, H.; Lund, T. \& Hansen, B.W. (2006). Effect of cold storage upon eggs of a calanoid copepod Acartia tonsa Dana and their offspring. Aquaculture 254:714-729.

Drillet, G.; Frouël, S.; Sichlau,M.H.; Jepsen P.M.; Højgaard,J.K.; Joarder, A.K. \& Hansen, B.W. (2011). Status and recommendations on marine copepod cultivation for use as live feed. Aquaculture 315, 155-166.

Dybdahl, M.F. (1995). Selection of life history traits across a wave exposure gradient in the tidepool copepod Tigriopus californicus (Baker). Journal of Experimental Marine Biology and Ecology 192:195-210.

Fava, G. \& Martini, E. (1988). Effect of inbreeding and salinity on quantitative characters and asymmetry of Tisbe holothuriae (Humes). Hydrobiologia 167/168:463-467. 
Gaudy, R.; Guerin, J.P. \& Moraitou-Apostolopoulou, M. (1982). Effect of temperature and salinity on the population dynamics of Tisbe holothuriae, Humes (Copepoda; Harpacticoida) fed two different diets. Journal of Experimental Marine Biology and Ecology 57:257-271.

Gee, J.M. (1989). An ecological and economic review of meiofauna as food for fish. Zoological Journal of the Linnean Society 96:243-261.

Geiling, W.T. \& Campbell, R.S. (1978). The effect of temperature on the development rate of the major life stages of Diaptomus pallidus Herrick. Hydrobiologia 61:304-307.

Gonzalez, C.R. \& Bradley, B.P. (1994). Salinity stress proteins in Eurytemora affinis. Hydrobiologia 292/293:461-468

Goolish, R. \& Burton, R. (1989). Energetics of osmoregulation in an intertidal copepod: effects of anoxia and lipid reserves on the pattern of free amino acid accumulation. Functional Ecology 3:81-89.

Guérin, J.P.; Kirchner, M. \& Cubizolles, F. (2001). Effects of Oxyrrhis marina (Dinoflagelata), bacteria and vitamin D2 on population dynamics of Tisbe holothuriae (Copepoda). Aquaculture 261:1-16.

Hagiwara, A.; Jung, M. \& Hiramaya, K. (1995). Interspecific relations between marine rotifers Branchionus rotundiformis and zooplankton species in the rotifer mass culture tanks. Fisheries Science 61:619-623.

Hall, C.J. \& Burns, C.W. (2002). Effects of temperature and salinity on the survival and egg production of Gladioferens pectinatus Brady (Copepodas: Calanoida). Estuarine, Coastal and Shelf Science 55:557-564.

Heinle, D.R. (1969). Temperature and zooplankton. Chesapeake Science 10:186-209.

Hicks, G.R.F. \& Coull, B.C. (1983). The ecology of marine meiobenthic harpacticoid copepods. Oceanography and Marine Biology: Annual Review 21:67-175.

Holmefjord, I.; Gulbrandsen, J.; Lein, I.; Refstie, T.; Léger, Ph. Harboe, T.; Huse, I.; Sorgeloos, P.; Bolla, S.; Olsen, Y.; Reitan, K.I.; Vadstein, O.; Øie G. \& Danielsberg, A. (1993). An intensive approach to Atlantic halibut fry production. Journal of World Aquaculture Society 24:275-284.

Kawall, H.G.; Torres, J.J. \& Geiger, S.P. (2001). Effects of the ice-edge boom and season on the metabolism of copepods in the Weddell Sea, Antarctica. Hydrobiologia 453/454:66-77.

Kimmel, D.G. \& Bradley, B.P. (2001). Specific protein responses in the calanoid copepod Eurytemora affinis (Poppe, 1880) to salinity and temperature variation. Journal of Experimental Marine Biology and Ecology 266:135-149.

Kinne, O. (1964). The effects of temperature and salinity on marine and brackish water animals: II. Salinity and temperature salinity combinations. Oceanography and Marine Biology: Annual Review 2:281-339.

Le Borgne, R. (1982). Zooplankton production in the eastern tropical Atlantic Ocean: net growth efficiency and P:B in term of carbon, nitrogen and phosphorus. Limnology and Oceanography 27:681-698.

Lee, C.E. \& Petersen, C.H. (2002). Genotype-by environment interaction for salinity tolerance in the freshwater invading copepod Eurytemora affinis. Physiological and Biochemical Zoology 75:335-344.

Lee, C.E.; Remfert, J.L. \& Gelembuik, G.W. (2003). Evolution of physiological tolerance and performance during freshwater invasions. Integrative and Comparative Biology 43:439-449 
Lonsdale, D.J. \& Levinton, J.S. (1986). Growth rate and reproductive differences in a widespread estuarine harpacticoid copepod (Scottolana canadensis). Marine Biology 91:231-237.

Lonsdale, D.J. \& Levinton, J.S. (1989). Energy budgets of latitudinally separated Scottolana Canadensis (Copepoda: Harpacticoida). Limnology and Oceanography 34:324-331.

Marcus, N.H. \& Murray, M. (2001). Copepod diapause eggs: a potential source of nauplii for aquaculture. Aquaculture 210:107-115.

Matias-Peralta, H.; Fatimah, M.Y.; Mohamed, S. \& Aziz, A. (2005). Effect of some environmental parameters on the reproduction and development of a tropical marine harpacticoid copepod Nitocra affinis f. californica Lang. Marine Pollution Bulletin 51:722-728.

McKinnon, A.D. (1996). Growth and development in the subtropical copepod Acrocalanus gibber. Limnology and Oceanography 41:1438-1447.

McKinnon, A.D.; Duggan, S.; Nichols, P.D.; Rimmer, M.A.; Semmens, G. \& Robino, B. (2003). The potential of tropical paracalanid copepods as live feeds in aquaculture. Aquaculture 223:8-106

McLaren, I. A.; Corkett, C. J. \& Zillioux, E. J. (1969).Temperature adaptations of copepod eggs from the arctic to the tropics. Biology Bulletin 137:486-493.

Milione, M. \& Zeng, C. (2008). The effects of temperature and salinity on population growth and egg hatching success of the tropical calanoid copepod, Acartia sinjiensis. Aquaculture 275:116-123.

Miliou, H. (1996). The effect of temperature, salinity and diet on final size of female Tisbe holothuriae (Copepoda: Harpacticoida). Crustaceana 69:742-753.

Miliou, H. \& Moraitou-Apostolopoulou, M. (1991). Combined effects of temperature and salinity on the population dynamics of Tisbe holothuriae Humes (Copepoda: Harpacticoida). Archives of Hydrobiology 121:431-448.

Naess, T.; Germain-Henry, M. \& Naas, K.E. (1995). First feeding of Atlantic halibut (Hippolossus hippoglossus) using different combination of Artemia and wild zooplankton. Aquaculture 130:235-250.

Nanton, D.A. \& Castell, J.D. (1998). The effects of dietary fatty acids on the fatty acid composition of harpacticoid copepods, Tisbe sp., for use as a live food for marine fish larvae. Aquaculture 163:251-261.

Palmer, M.A. \& Coull, B.C. (1980). The prediction of development rate and the effect of temperature for the meiobenthic copepod, Microarthridion littorale (Pope). Journal of Experimental Marine Biology and Ecology 48:73-83.

Penchenik, J.A. (2005). Biology of the invertebrates. Fifth Edition. Tufts University. McGrawHill. 608pp.

Pepin, P. \& Penney, R.W. (1997). Patterns of prey size and taxonomic composition in larval fish: are there general size dependent models? Journal of Fish Biology 51:84-100.

Peterson, W.T. (2001). Patterns in stage duration and development among marine and freshwater calanoid and cyclopoid copepods: a review of rules, physiological constraints, and evolutionary significance. Hydrobiologia 453/454:91-105.

Pinto, C.S.C.; Souza-Santos, L.P. \& Santos, P.J.P. (2001). Development and population dynamics of Tisbe biminiensis (Copepoda: Harpacticoida) reared on different diets. Aquaculture 198:253-267. 
Rippingale, R.J. \& Payne, M.F. (2001). Intensive cultivation of a calanoid copepod, Gladioferens imparipes. A guide to procedures. Department of Environmental Biology, Curtin University of Technology, Perth. 62pp.

Rhodes, A.C.E. (2003). Marine harpacticoid copepod culture for the production of long chain highly unsaturated fatty acids and carotenoid pigments. A dissertation submitted to the Graduate Faculty of North Carolina State University in partial fulfillment of the requirements for the Degree of Doctor of Philosophy. 161pp.

Rhyne, A.L.; Ohs, C.L. \& Stenn, E. (2009). Effects of temperature on reproduction and survival of the calanoid copepod Pseudodiaptomus pelagicus. Aquaculture 292:53-59.

Siokou-Frangou, I. 1996. Zooplankton annual cycle in a Mediterranean coastal area. Journal of Plankton Research 18:203-223.

Staton, J.L.; Schizas, N.V.; Klosterhaus, S.L.; Griffitt, R.J.; Chandler, G.T. \& Coull B.C. (2002). Effect of salinity variation and pesticide exposure on an estuarine harpacticoid copepod, Microarthridion littorale (Poppe), in the southeastern US. Journal of Experimental Marine Biology and Ecology 278:101-110

Støttrup, J.G. \& Norsker, N.H. (1997). Production and use of copepods in marine fish larviculture. Aquaculture 155:231-247.

Sun, B. \& Fleeger, J.W. (1995). Sustained mass culture of Amphiascoides atopus, a marine harpacticoid copepod in a recirculating system. Aquaculture 136:313-321.

Takahashi, T. \& Ohno, A. (1996). The temperature effect on the development of calanoid copepod, Acartia tsuensis, with some comments to morphogenesis. Journal of Oceanography 52:125-137.

Tester, P.A. \& Turner, J.T. (1990). How long does it take copepods to make eggs?. Journal of Experimental Marine Biology and Ecology 141:169-182.

Uye, S.I. (1985). Resting egg production as a life history strategy of marine planktonic copepods. Bulletin of Marine Research 37:440-449

Uriarte, I.; Cotano, U. \& Villate, F. (1998). Egg production of Acartia bifilosa in the small temperate estuary of Mundaka, Spain, in relation to environmental variables and population development. Marine Ecology: Progress Series 166:197-205

Van der Meeren, T. (1991). Selective feeding and prediction of food consumption in turbot larvae (Scopthalmus maximus L.) reared on the rotifer Brachionus plicatilis and natural zooplankton. Aquaculture 93:35-55.

Vincx, M. (1996). Meiofauna in marine and freshwater sediment. In: Hall, G. S. (editor) Methods for the Examination of Organism Diversity in Soils and Sediments. CAB International. pp 187-195.

Von Herbing, H. \& Gallagher, S. (2000). Foraging behavior in early Atlantic cod larvae (Gadhus morhua) feeding on a protozoan (Balanion sp.) and a copepod nauplius (Pseudodiaptomus sp.). Marine Biology 136:591-602

Williams, T.D. \& Jones, M.B. (1994). Effects of temperature and food quantity on postembryonic development of Tisbe battagliai (Copepoda: Harpacticoida). Journal of Experimental Marine Biology and Ecology 183:283-298.

Williams, T.D. \& Jones, M.B. (1999). Effect of temperature and food quantity on the reproduction of Tisbe battagliai (Copepoda: Harpacticoid). Journal of Experimental Marine Biology and Ecology 236:273-290.

Zaleha, K. \& Farahiyah-Ilyana J. (2010). Culture and growth of a marine harpacticoid, Pararobertsonia sp. in different salinity and temperature. Sains Malaysiana 39(1): 137-141. 


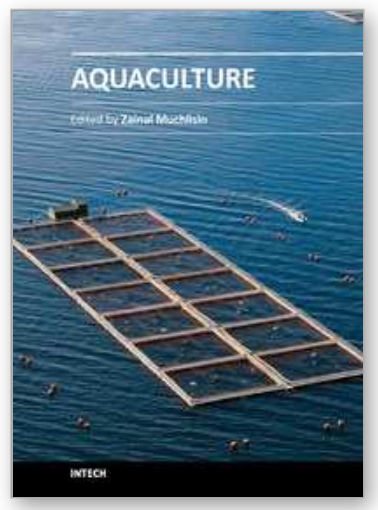

\author{
Aquaculture \\ Edited by Dr. Zainal Muchlisin
}

ISBN 978-953-307-974-5

Hard cover, 390 pages

Publisher InTech

Published online 27, January, 2012

Published in print edition January, 2012

This book provides an understanding on a large variety of aquaculture related topics. The book is organized in four sections. The first section discusses fish nutrition second section is considers the application of genetic in aquaculture; section three takes a look at current techniques for controlling lipid oxidation and melanosis in Aquaculture products. The last section is focused on culture techniques and management, , which is the larger part of the book. The book chapters are written by leading experts in their respective areas. Therefore, I am quite confident that this book will be equally useful for students and professionals in aquaculture and biotechnology.

\title{
How to reference
}

In order to correctly reference this scholarly work, feel free to copy and paste the following:

Kassim Zaleha and Ibrahim Busra (2012). Culture of Harpacticoid Copepods: Understanding the Reproduction and Effect of Environmental Factors, Aquaculture, Dr. Zainal Muchlisin (Ed.), ISBN: 978-953-307-974-5, InTech, Available from: http://www.intechopen.com/books/aquaculture/copepods-in-aquaculture

\section{INTECH}

open science | open minds

\section{InTech Europe}

University Campus STeP Ri

Slavka Krautzeka 83/A

51000 Rijeka, Croatia

Phone: +385 (51) 770447

Fax: +385 (51) 686166

www.intechopen.com

\section{InTech China}

Unit 405, Office Block, Hotel Equatorial Shanghai

No.65, Yan An Road (West), Shanghai, 200040, China

中国上海市延安西路65号上海国际贵都大饭店办公楼 405 单元

Phone: +86-21-62489820

Fax: +86-21-62489821 
(C) 2012 The Author(s). Licensee IntechOpen. This is an open access article distributed under the terms of the Creative Commons Attribution 3.0 License, which permits unrestricted use, distribution, and reproduction in any medium, provided the original work is properly cited. 